\title{
Rappresentazioni tattili
}

\author{
Vincenza Garofalo \\ Elisa Azzurra Conigliaro \\ Alessia Tzimas
}

Abstract

Sebbene molto spesso le persone con disabilità debbano accontentarsi di vivere parzialmente alcune esperienze, da diversi anni è aumentata l'attenzione dei siti museali verso la realizzazione di progetti e percorsi dedicati che consentano una fruizione tattile di opere e manufatti ai disabili visivi.

Il contributo presenta due casi studio, che utilizzano modelli 3D per installazioni tattili.

In presenza di deficit visivo, è importante rafforzare le facoltà percettive connettendo il tatto con i sensi residui e fornendo stimoli cognitivi diversi e paralleli. L'approccio multisensoriale, tattile e uditivo, realizzato grazie alla commistione tra modelli 3D e componenti elettroniche, favorisce la capacità di astrazione e percezione, consente di fruire della riproduzione in una condizione in cui non può essere fruita l'opera originale e rende comprensibile il processo rappresentativo. Rappresentare è comunicare la conoscenza che si esplora con l'esperienza multisensoriale.
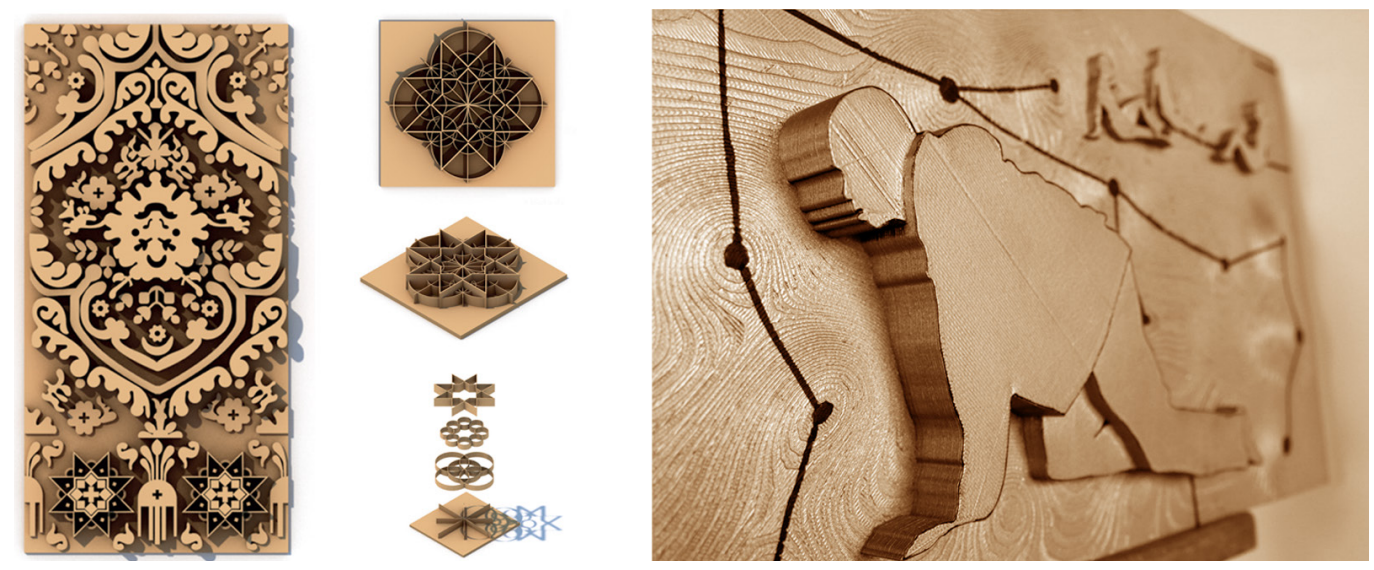


\section{Introduzione}

Consentire l'accessibilità alle opere d'arte e ai luoghi di interesse culturale è fondamentale per garantire la piena fruizione, agevole e autonoma, ai disabili [ I ]. A tale scopo nel 2006 è stata approvata la Convenzione ONU sui diritti delle persone con disabilità (Convention on the Rights of Persons with Disabilities) [2] e nel 2008 in Italia il MIBACT (Ministero dei beni e delle attività culturali e del turismo) ha redatto le Linee guida per il superamento delle barriere architettoniche nei luoghi di interesse culturale [3].

Sebbene molto spesso le persone con disabilità debbano accontentarsi di vivere parzialmente alcune esperienze, da diversi anni è aumentata l'attenzione dei siti museali verso la realizzazione di progetti e percorsi dedicati che consentano una fruizione tattile di opere e manufatti ai disabili visivi. In Italia sono già attive molte realtà museali che hanno attuato buone pratiche per consentire l'accessibilità alle opere artistiche [4].

Tra queste, due realtà sono prevalentemente dedicate ai disabili visivi. II Museo Tattile Statale Omero di Ancona è una struttura dedicata all'esplorazione sensoriale, nata per consentire ai non vedenti di conoscere l'arte e l'architettura attraverso il tatto [5]. II Museo tattile di Pittura antica e moderna Anteros dell'Istituto dei Ciechi Francesco Cavazza di Bologna ospita una vasta collezione di riproduzioni tridimensionali di dipinti celebri [6].

L'approccio alla lettura tattile di rappresentazioni pittoriche, tradotte in bassorilievo, richiede al disabile la capacità di mettersi in percezione dell'ambiente esterno usando i sensi residui extra visivi, per giungere a un rafforzamento delle proprie facoltà percettive, cognitive e intellettuali (fig. I).

Ciò richiede una preparazione preliminare alla lettura che predisponga non solo all'esplorazione degli oggetti reali, ma anche alla loro rappresentazione (figg. 2, 3).

"Avvicinare un non vedente alla pittura iconica significa non solo avvicinarlo all'arte visiva che, se figurativa e/o mimetica, copia la realtà e la trasfigura, ma anche introdurlo al principio di aberrazione ottica e spiegargli che ciò che la visione retinica percepisce è un'illusione ottica che la mente decodifica al fine di intuire la reale fisionomia dell'oggetto osservato e la nozione convenzionale che ne giustifica la rappresentazione aberrata" [7].

Fig. I. Museo Anteros. Riproduzione del Cristo morto di Andrea Mantegna. Bassorilievo prospettico. Mic pic / CC BY-SA: < https://creativecommons.org/licenses/ by-sa/4.0>.

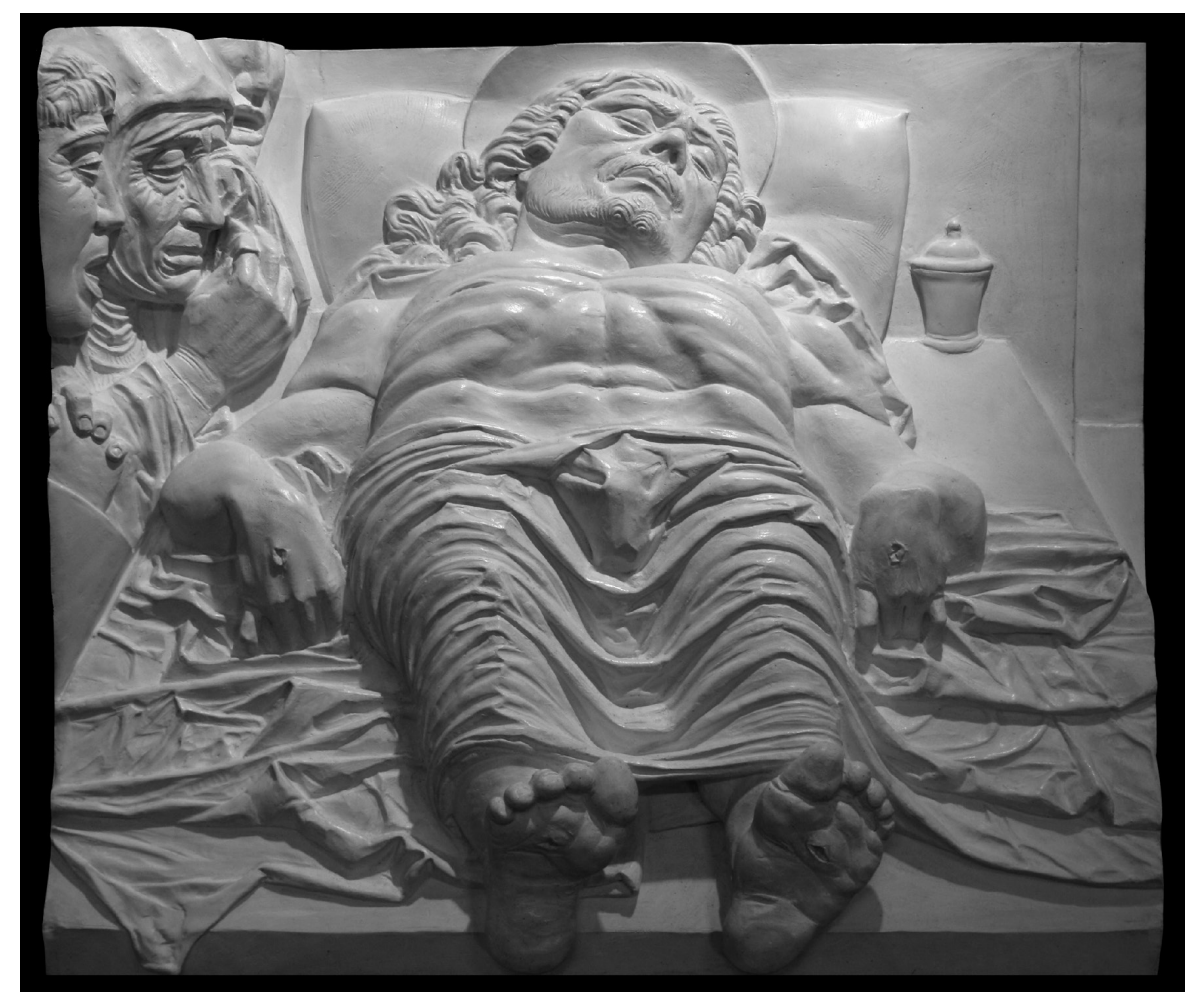




\section{L'esplorazione tattile}

"Un cieco, toccando un oggetto, ne delinea i contorni come un vedente per il quale, guardare un oggetto, una persona, significa staccarla dallo sfondo, metterla a fuoco, disegnarla, delinearla con la mente" [8]. Tra le forme di esplorazione sensoriale, quella tattile consente al disabile visivo di concepire un patrimonio immaginativo aderente alla realtà e di raggiungere una rappresentazione mentale dell'opera d'arte. Tale rappresentazione si costruisce attraverso un processo analitico e graduale, che si realizza nel tempo e che richiede capacità di astrazione e memoria. Tuttavia, l'eccesso di informazione può generare confusione. Pertanto, è importante che la realizzazione di modelli 3D per non vedenti sia preceduta da un'attenta analisi e discretizzazione delle caratteristiche principali da riprodurre. II disegno da riprodurre tridimensionalmente deve essere semplice, chiaro e sintetico. II tatto, infatti, "è analitico e la percezione dell'insieme si ottiene attraverso l'organizzazione della sequenza delle informazioni parziali. La sintesi è dunque un processo complesso e può diventare difficile se la rappresentazione supera certe dimensioni (pari all'apertura completa di due mani accostate). Inoltre la discriminazione tattile è limitata e incapace di cogliere particolari molto piccoli, per cui questi devono essere rappresentati sicuramente più grandi rispetto a quelli percepibili dalla vista" [9].

Fig. 2. Museo Anteros. Tavola tattile propedeutica all'apprendimento della prospettiva: $<$ www cavazza.it>.

Fig. 3. Museo Anteros. Tavola tattile propedeutica all'apprendimento calla della prospettiva: $<$ wmw cavazza.it>

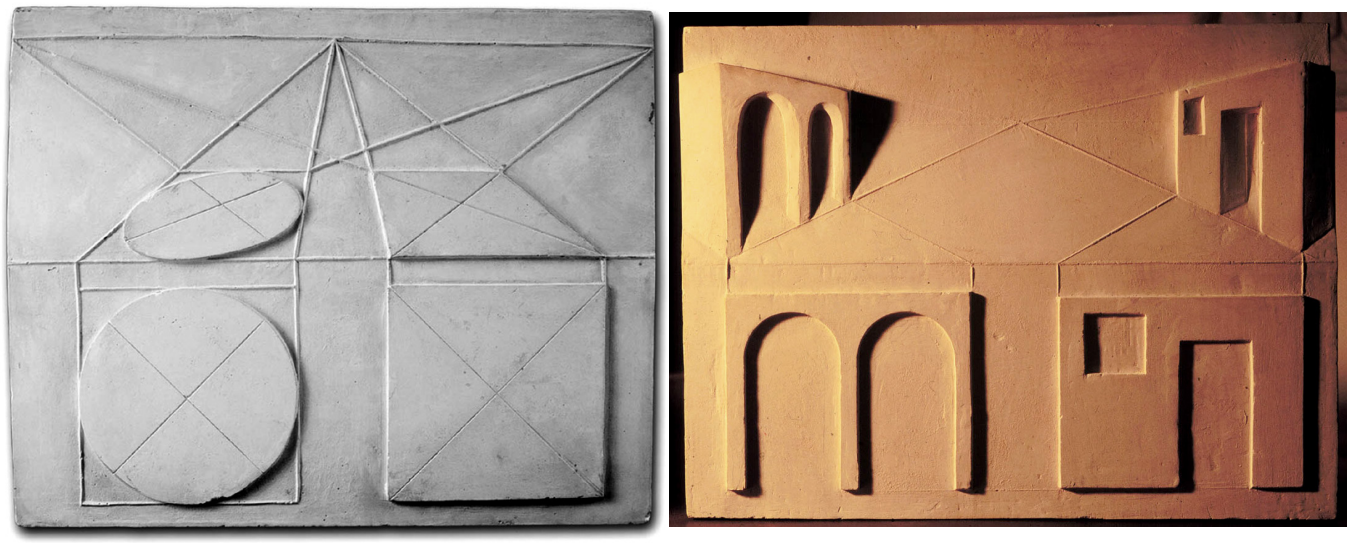

Il contributo presenta due casi studio, che utilizzano modelli 3D per installazioni tattili [10]. Il primo riguarda la realizzazione di modelli per una mostra fotografica dedicata alle migrazioni, a partire da fotografie sul tema. Sono stati scelti due scatti. Il primo è del fotografo argentino Juan Medina e raffigura un migrante che si muove carponi tra i bagnanti su una spiaggia delle Canarie, sulla quale è appena approdato. II secondo è uno scatto di Sebastiao Salgado realizzato in Ecuador nel 1998 e rappresenta una lunga fila di donne ecuadoregne in cammino verso la città per vendere i prodotti dei loro villaggi. II processo di comprensione attraverso il tatto si attua con il riconoscimento delle forme, della composizione dell'immagine e dello spazio prospettico, per rappresentare il quale, entrambi i modelli 3D presentano i soggetti su diversi livelli, rispetto al piano di posa. La realizzazione del modello digitale è avvenuta per fasi successive: analisi delle immagini e selezione degli elementi da riprodurre, rappresentazione bidimensionale delle linee di contorno ed estrusione delle stesse a diverse altezze per simulare i piani di profondità della composizione (figg. 4, 5).

Il secondo caso studio, pensato per un percorso museale permanente, riguarda una installazione che, mediante l'esplorazione tattile, permette la comprensione dell'articolato decoro del tessuto di una cintura nuziale marocchina. In questo caso, poiché il modello è realizzato in materiale diverso dall'originale, accanto alla riproduzione tattile si prevede di porre dei campioni di stoffa con ricami, per simulare la sensazione che si riceve dal toccare l'opera autentica. 


\section{Migrazioni. Un progetto fotografico}

Il progetto prevede la realizzazione di un modello in stampa 3D pensato per una mostra fotografica provisto di touch sensoriale che aiuta i non vedenti alla percezione dell'opera attraverso suoni.

II primo passo ha riguardato l'analisi della foto, al fine di individuare le linee principali da rappresentare. A tal fine, si è proceduto alla discretizzazione della composizione, per evidenziare i concetti da trasmettere e per rendere comprensibile la lettura dell'opera al disabile visivo. Per quanto riguarda la riproduzione della foto di Medina, per procedere alla rappresentazione della spiaggia, che occupa l'area maggiore dello scatto fotografico, si è utilizzato Blender. A partire da una mesh, sono state assegnate varie altezze ai suoi vertici, al fine di simulare la profondità prospettica della superficie della spiaggia. II software Rhinoceros è stato utilizzato, invece, per disegnare i contorni che rappresentano l'uomo in primo piano della scena, le tre figure dei bagnanti che si trovano in secondo piano e il cielo. I contorni

Fig. 4. Realizzazione del modello 3D che riproduce la fotografia di Sebastio Salgado (elaborazion grafica Elisa Azzurra Conigliaro).
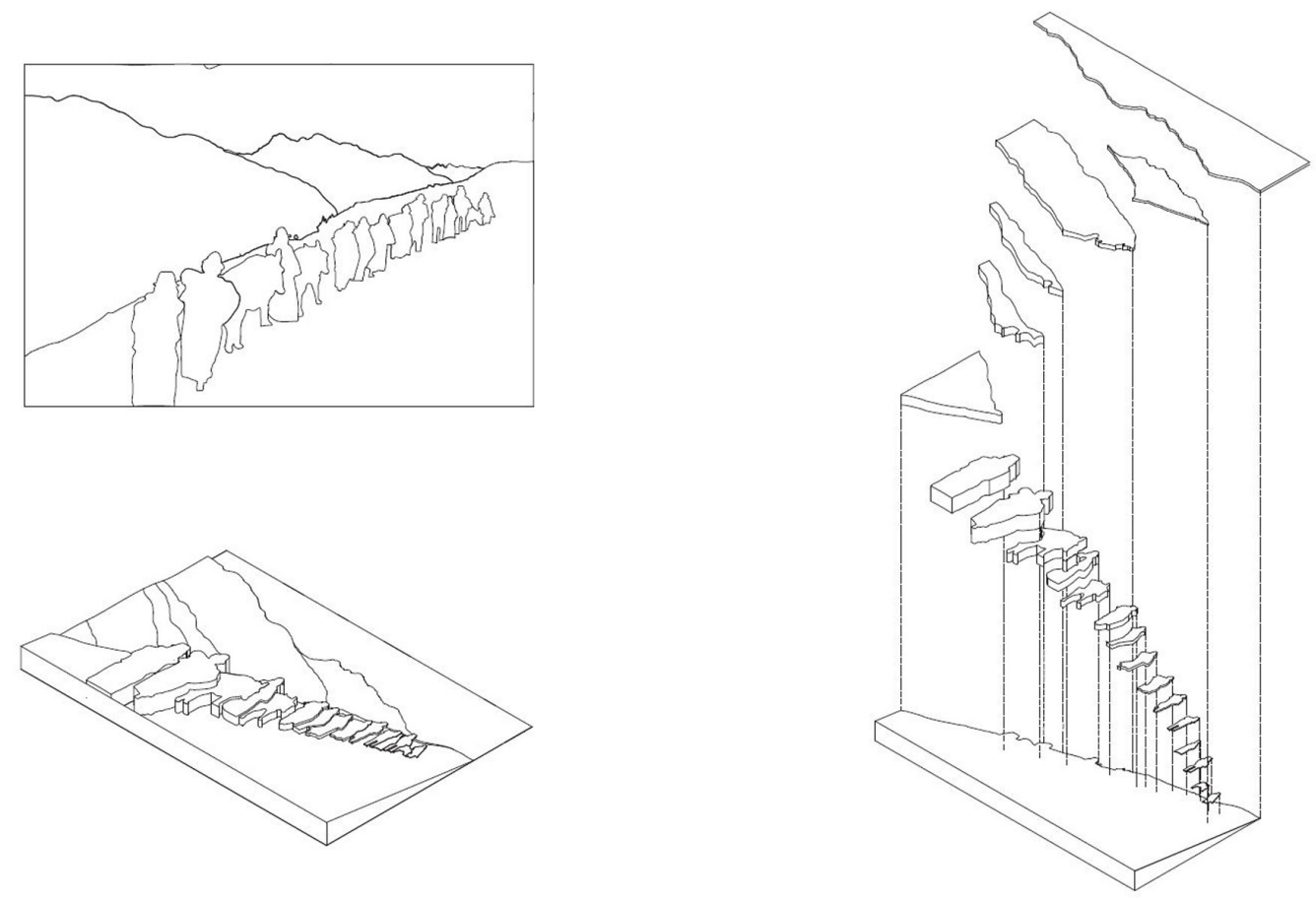

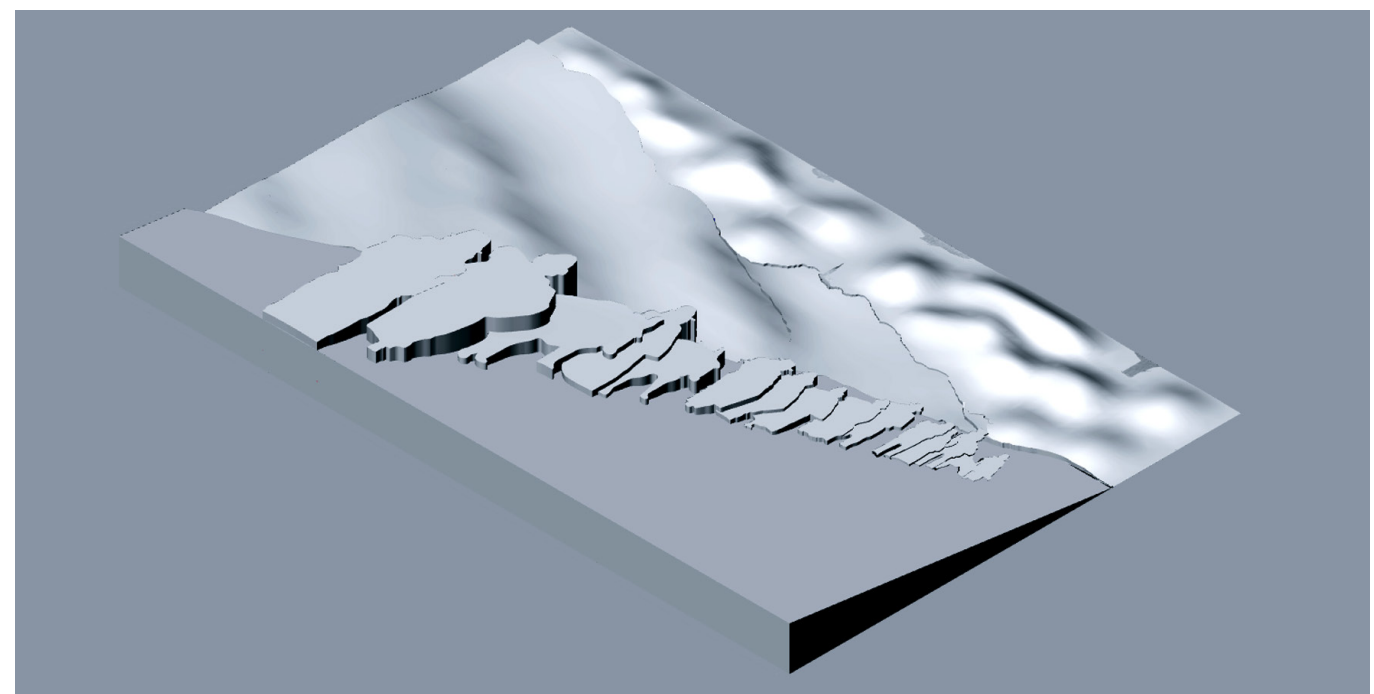


Fig. 6. Realizzazione del modello 3D che riproduce la fotografia di Juan Medina (elaborazione grafica Elisa Azzurra Conigliaro).
Fig. 7. Modello 3D che riproduce la fotografia di Juan Medina

(elaborazione grafica Elisa Azzurra Conigliaro).

degli elementi della scena prima descritti sono stati estrusi, attribuendo ad essi altezze differenti, al fine di simulare la prospettiva dello scatto (fig. 6). II modello ottenuto da Blender ed esportato in formato STL è stato importato in Rhinoceros, completando così la riproduzione tridimensionale dell'intera scena fotografica (fig. 7). II modello digitale completo, così ottenuto, è stato, infine, esportato in formato STL ed inviato alla stampante 3D per essere convertito in un modello fisico.

Per rendere l'esperienza ancora più immersiva, si è scelto di collegare al modello fisico alcuni suoni che possano evocare il contesto sonoro dell'ambiente rappresentato. Ciò è stato possibile grazie all'applicazione, in alcuni punti prescelti, di una vernice elettroconduttrice, che disegna un circuito tattile collegato a una scheda elettronica associata, capace di trasmettere un input mediante il tocco delle mani (fig. 8). I suoni scelti evocano lo sciabordio delle onde, le voci dei bagnanti, i passi sulla sabbia e il lamento del naufrago. Tali suoni vengono attivati quando la mano, nel suo percorso esplorativo, incontra i punti sensibili del modello impregnati dalla vernice e che corrispondono al soggetto al quale è attribuito il suono stesso. II
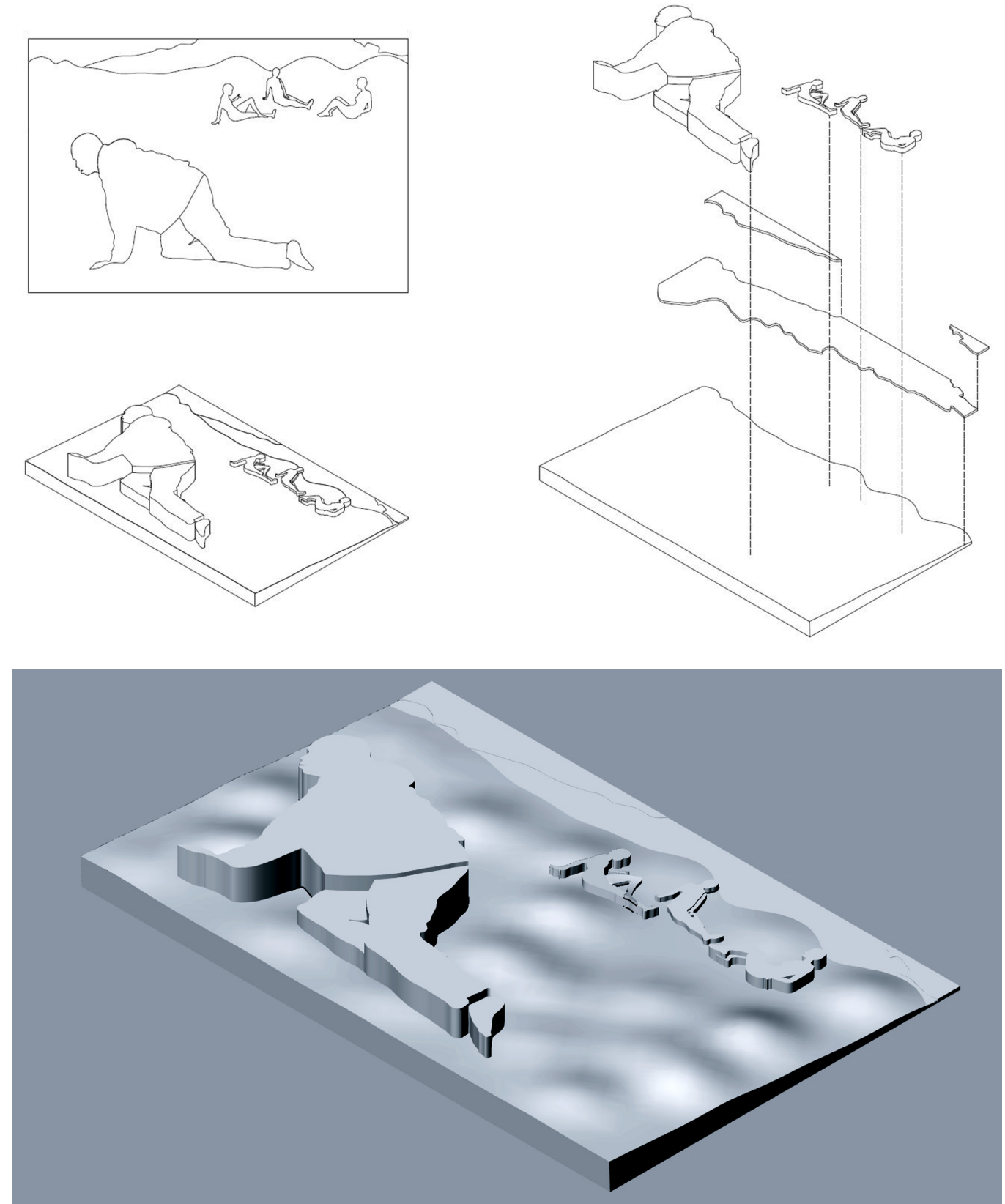
disabile visivo, che esplora un oggetto, prima ne tocca i bordi e le superfici e poi si sofferma sui dettagli. Pertanto, toccando il profilo esterno del modello fisico, si può ascoltare solo il suono del mare e, via via, sfiorando tutti gli altri elementi della composizione, è possibile udire anche gli altri suoni. In tal modo, il non vedente compie l'esperienza totale dello scatto fotografico.

Fig. 8. Riproduzione tattile con il circuito elettrico (elaborazione grafica Elisa Azzurra Conigliaro).

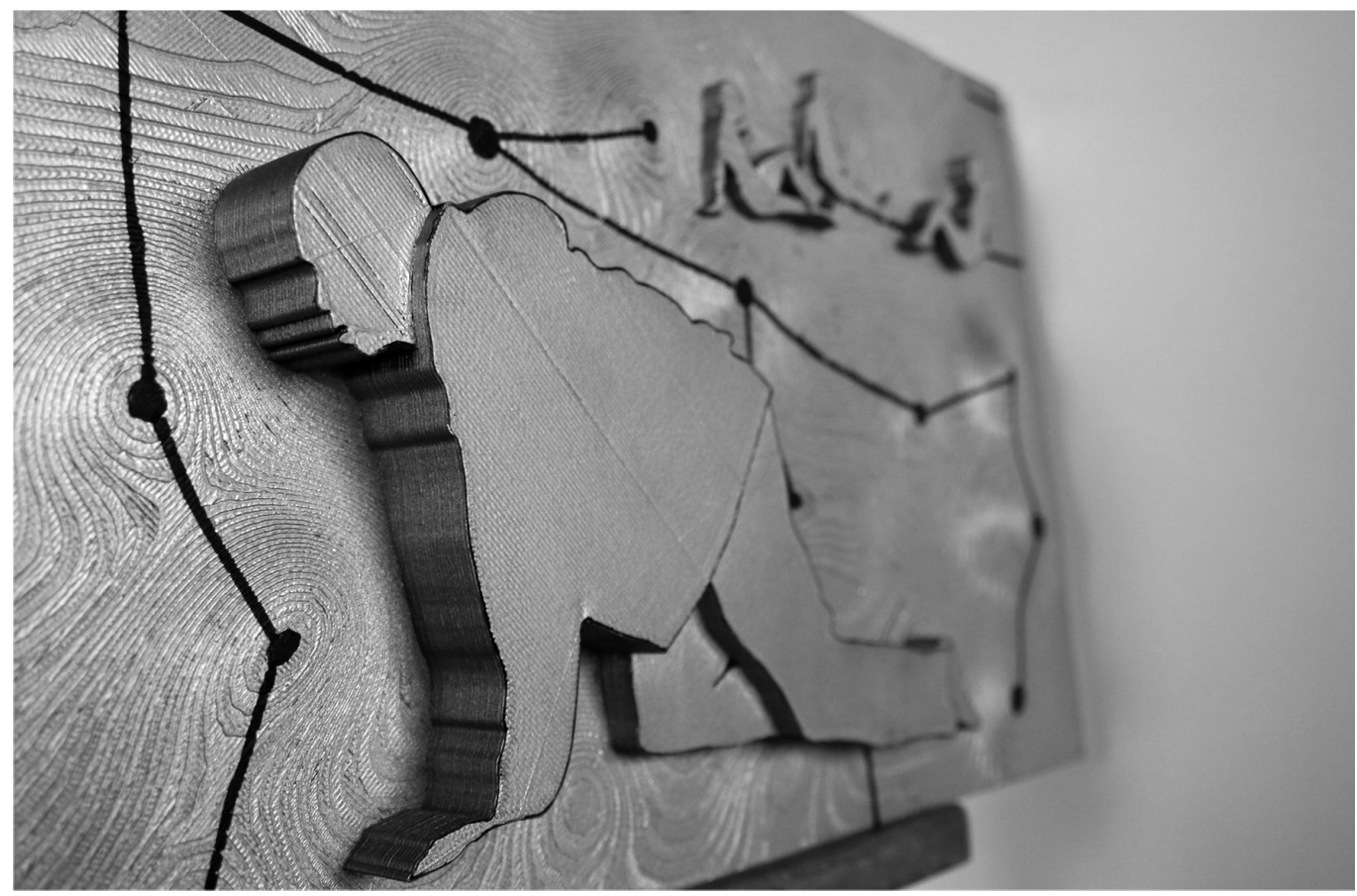

\section{Trame tattili}

Il Museo delle Trame Mediterranee di Gibellina ospita opere che raccontano la storia culturale del Mediterraneo attraverso la comparazione dei manufatti, il confronto delle forme, delle tecniche e delle decorazioni. L'installazione tattile, che qui si presenta, è stata progettata nell'ambito di un percorso museale multisensoriale, pensato per il Museo, che consiste nell'integrazione tra la descrizione tattile delle opere e il percorso guidato dai sensi. II percorso si snoda lungo tre sale: la prima riguarda il tatto e l'esplorazione dei tessuti, la seconda concerne l'olfatto e la descrizione delle ceramiche, la terza è dedicata all'udito e all'esplorazione dettagliata delle tavole che analizzano i decori degli oggetti della collezione esposta. Per guidare i visitatori non vedenti o ipovedenti lungo il percorso museale, si prevede di fornire loro una card provvista di due chip. II primo consente a un computer collegato di rilevare la presenza dei visitatori; a tale scopo, occorre eseguire preliminarmente la mappatura 3D delle sale. I visitatori possono spostarsi liberamente e autonomamente ottenendo, attraverso il chip, le informazioni istantanee di quanto avviene negli spazi. II secondo chip utilizza la tecnologia di identificazione automatica RFID (Radio Frequency Identification) che si basa sulla propagazione nell'aria di onde elettro-magnetiche, consentendo la rilevazione automatica e a distanza di oggetti e persone statiche e in movimento. Un software di sintesi vocale permette al disabile di ricevere, attraverso un auricolare bluetooth, le informazioni vocali sul percorso da seguire, gli eventuali ostacoli o i punti di interesse nella sala.

Per simulare una delle installazioni tattili della sala destinata all'esplorazione dei tessuti, si è scelto di rappresentare un elemento della collezione del museo. Si tratta di una lunga cintura, databile agli inizi del XIX secolo, che fa parte dell'abito nuziale maschile adoperato in molte comunità del sud del Marocco (fig. 9). Realizzata con tessuti preziosi e motivi che 
Fig. 9. Cintura marocchina: al centro la trama, a destra l'analisi dei colori (elaborazione gefica (elaborazione gra cic
Fig. 10. Analisi geometrica dei decori della cintura

(elaborazione grafica

(elaborazione
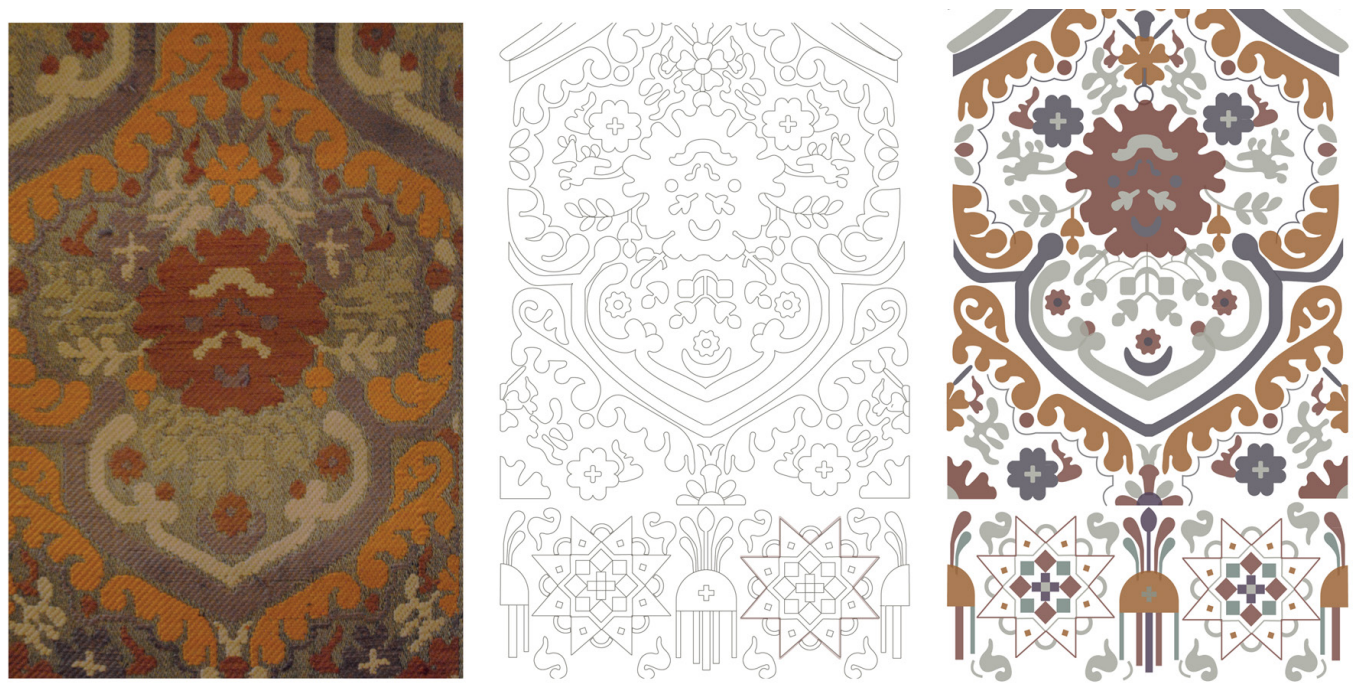

mostrano articolati intrecci a sviluppo alternato su tutta la lunghezza, è una testimonianza del linguaggio decorativo islamico. La marcata geometria delle forme e la loro costante ripetitività sono strettamente legate a ragioni di tipo religioso, poiché la spiritualità musulmana vede nella contemplazione delle forme ripetute all'infinito la possibilità di raggiungere il divino.

La parte finale della cintura mostra il motivo delle due stelle a otto punte ruotate, tipico della tradizione islamica e riscontrabile in vari oggetti della collezione del Museo, provenienti da luoghi differenti e realizzati in periodi diversi.

Al fine di realizzare una rappresentazione tattile che rendesse comprensibili le trame dei tessuti ai non vedenti, sono state, preliminarmente, analizzate le geometrie e la composizione del decoro (figg. I0, I I). Tali geometrie sono state estruse per realizzare un modello 3D, attribuendo una differente altezza alle aree della cintura di diverso colore (fig. I2). Questo procedimento è stato finalizzato a restituire al fruitore una corrispondenza tra colori e geometrie più vicina possibile alla composizione del manufatto. Il processo di modellazione è stato preliminare alla stampa 3D di un pannello che riproduce la cintura e che può essere fruito dal disabile visivo usando il tatto. Si prevede, inoltre, la possibilità di utilizzare texture riconoscibili al tatto da applicare alle superfici del modello per differenziare ulteriormente i colori.
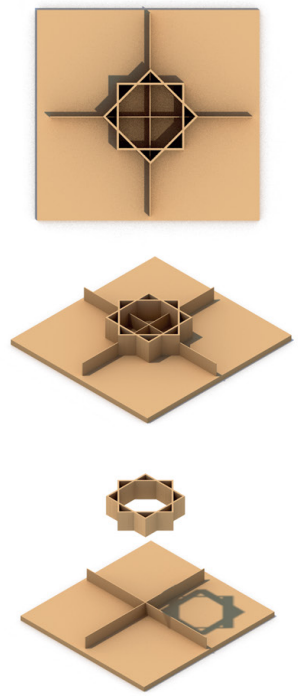
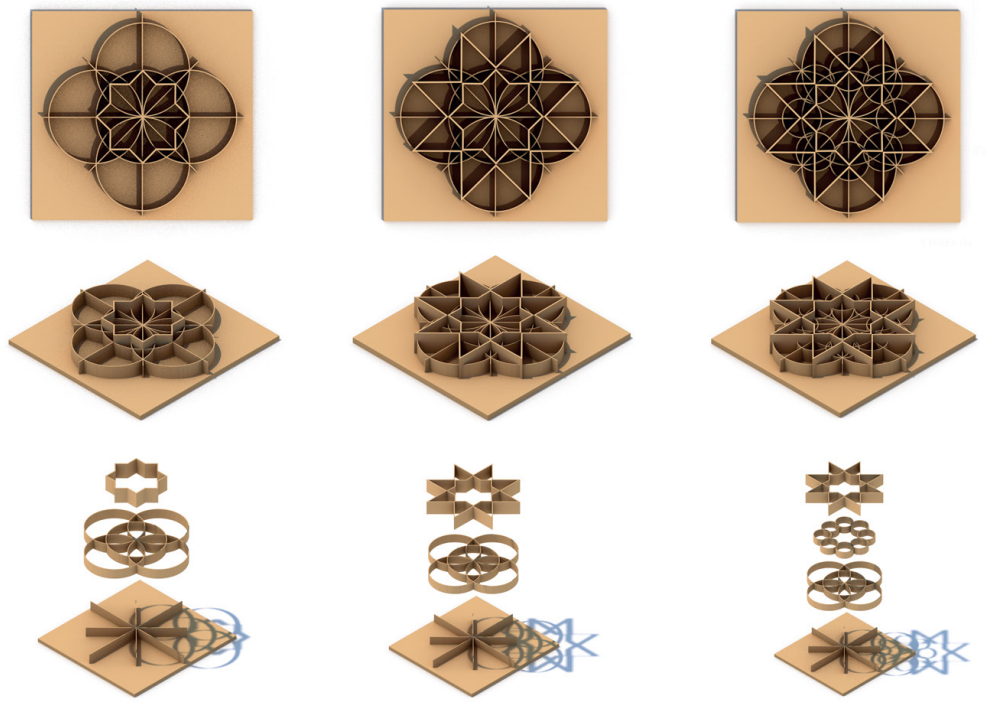


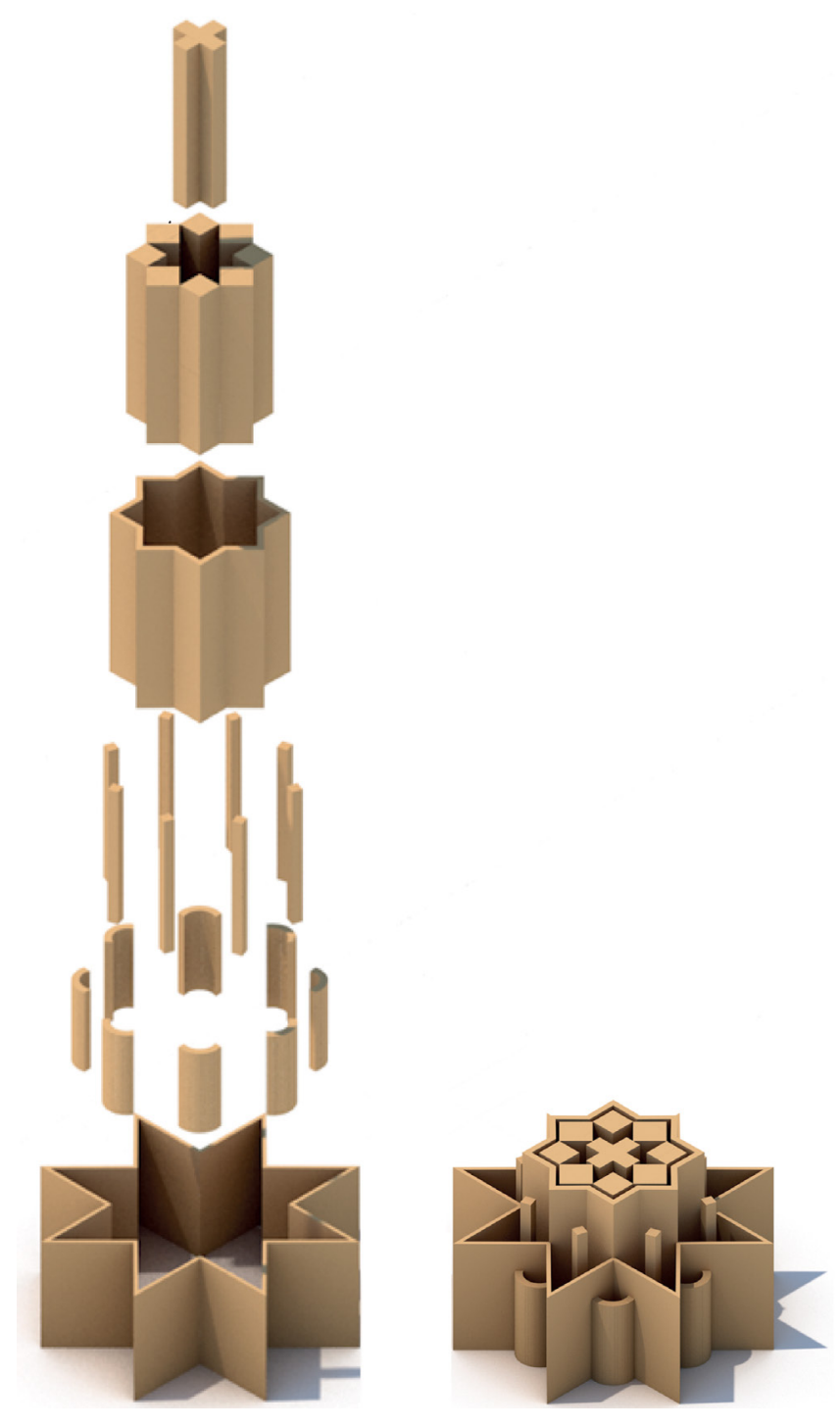

Fig. 12. II modello 3D digitale della parte terminale

della cintura: le diverse

altezze di estrusione

indicano colori differenti

(elaborazione grafica
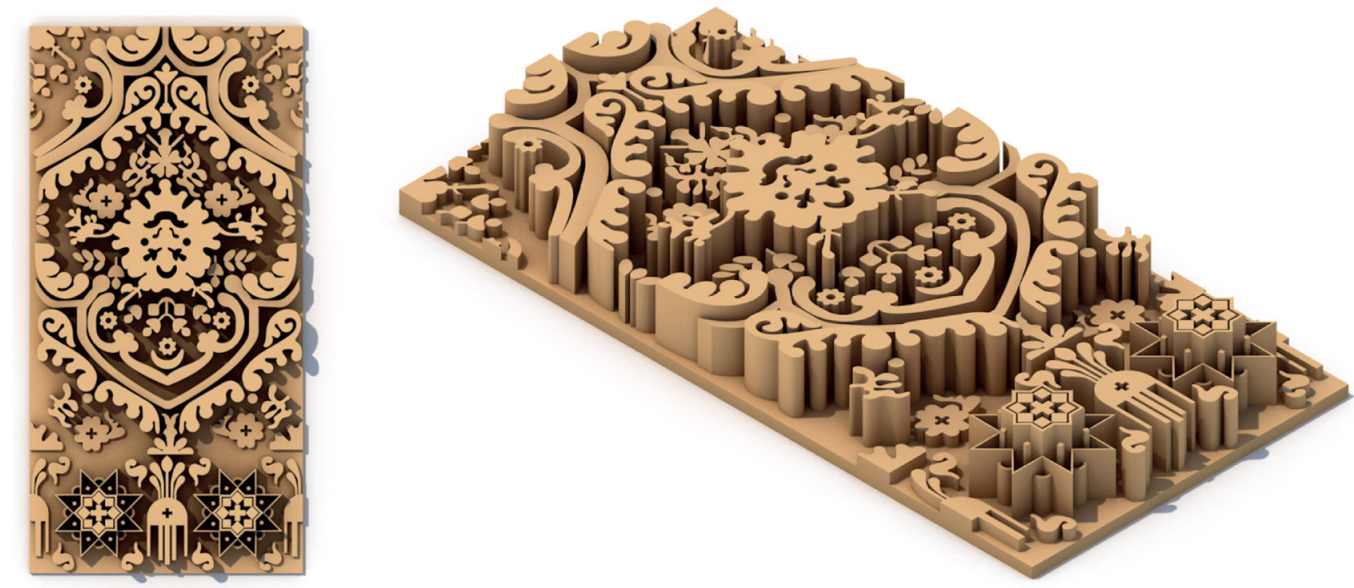


\section{Conclusioni}

I due progetti di installazione per disabili visivi qui presentati hanno una doppia valenza didattica e inclusiva. II carattere didattico risiede nella possibilità per i non vedenti di conoscere le opere analizzate mediante la loro rappresentazione tridimensionale, che si costruisce a seguito di un attento processo di analisi delle forme e di trasmissione del significato. L'aspetto inclusivo è quello che rende le opere accessibili, comprensibili e fruibili, consentendo ai disabili visivi di eliminare le barriere.

In presenza di deficit visivo, è importante rafforzare le facoltà percettive connettendo il tatto con i sensi residui e fornendo stimoli cognitivi diversi e paralleli. L'approccio multisensoriale, tattile e uditivo, realizzato grazie alla commistione tra modelli 3D e componenti elettroniche, favorisce la capacità di astrazione e percezione, consente di fruire della riproduzione in una condizione in cui non può essere fruita l'opera originale e rende comprensibile il processo rappresentativo. Rappresentare è comunicare la conoscenza che si esplora con l'esperienza multisensoriale.

\section{Note}

[I] II paragrafo "L'esplorazione tattile", insieme all'Introduzione e alle Conclusioni è scritto da Vincenza Garofalo. II paragrafo "Migrazioni. Un progetto fotografico" è di Elisa Azzurra Conigliaro, mentre il paragrafo "Trame tattili" è di Alessia Tzimas.

[2]Vedi: <https://unric.org/it/wp-content/uploads/sites/3/2019/I2/Convenzione_ONU-2.pdf>.

[3]Vedi: <https://www.beniculturali.it/mibac/multimedia/MiBAC/documents/I 3 | I 244354 I 28_plugin-LINEE_GUIDA_PER_IL_ SUPERAMENTO_DELLE_BARRIERE_ARCHITETTONICHE.pdf>

[4] L'elenco aggiornato delle istituzioni museali che presentano esposizioni fruibili e percorsi dedicati è consultabile alla pagina: <https://www.uiciechi.it/documentazione/paginetematiche/autonomia/elencazione\%20siti\%20museali20 I9.doc>. Per accedere, invece, alle informazioni sulle caratteristiche di accessibilità dei musei e delle aree archeologiche si può consultare il sito del MIBACT alla pagina <https://www.accessibilitamusei.beniculturali.it/luoghi-cultura/index>.

[5]Vedi: < http://www.museoomero.it>.

[6]Vedi: <https://www.cavazza.it/museoanteros>.

[7] Secchi Loretta, Gualandi Paolo (2006). Logiche di ideazione e realizzazione della pittura tridimensionale per una didattica speciale delle arti. In Museo Tattile Statale Omero (a cura di). L'arte a portata di mano, Roma: Armando Editore.

[8] Guerra Lisi Stefania, Stefani Gino (2006). Sinestesia e MusicArTerapia nella Globalità dei Linguaggi. In Museo Tattile Statale Omero (a cura di). L'arte a portata di mano, Roma: Armando Editore, pp. 70-7I.

[9]Vedi: <https://www.beniculturali.it/mibac/multimedia/MiBAC/documents/I3 | 1 244354 I 28_plugin-LINEE_GUIDA_PER_IL_ SUPERAMENTO_DELLE_BARRIERE_ARCHITETTONICHE.pdf>, pp. 23-24.

[10] La stampa 3D permette di ottenere modelli fisici che, sebbene siano attendibili per le caratteristiche geometriche e dimensionali, presentano, tuttavia, superfici non lisce al tatto. Le asperità del materiale non sono adatte alla esplorazione tattile, pertanto è consigliabile prevedere la levigatura del modello stampato per perfezionare le qualità della sua superficie.

\section{Riferimenti bibliografici}

Arnheim Rudolf (1994). Per la salvezza dell'arte. Milano: Feltrinelli.

Bellini Andrea (a cura di). (2000). Toccare l'arte. L'educazione estetica di ipovedenti e non vedenti. Roma: Armando Editore.

Conigliaro Elisa Azzurra (2018). Migrazioni. Un progetto fotografico tattile. Tesi di laurea, Università di Palermo. Relatore prof. Vincenza Garofalo.

Gombrich Ernst H., Hochberg Julian, Black Max (1978). Arte, percezione e realtà. Torino: Einaudi.

Lederman Susan J., Klatzky Roberta L. (1987). Hand Movements: A window into Haptic Object Recognition. In Cognitive Psychology, 19, pp. 342-68.

Merleau-Ponty Maurice (2003). Fenomenologia della percezione. (Traduzione di Andrea Bonomi). Milano: Bompiani. (Ed. orig. (1945) Phénoménologie de la perception. Paris: Gallimard).

Mottola Molfino Alessandra (2004). L'etica dei musei. Torino: Umberto Allemandi.

Museo Tattile Statale Omero (a cura di). (2006). L'arte a portata di mano. Roma: Armando Editore.

Pallasmaa Juhani (2007). Gli occhi della pelle. L'architettura e i sensi. Prefazione di Steven Holl. Milano: Jaca Book. (Ed. orig. (2005) The Eyes of the Skin. Architecture and the Senses). New York: John Wiley. 
Secchi Loretta (2007). Andrea Mantenga e la didattica speciale: nuove acquisizioni del Museo Anteros di Bologna. In Bollettino Anisa (Associazione Nazionale Insegnanti Storia dell'Arte) 27, Gennaio-Agosto, pp. 40-57.

Tzimas Alessia (2016). Trame tattili. Un percorso multimediale per il museo di Gibellina. Tesi di laurea, Università di Palermo. Relatore prof.Vincenza Garofalo.

sitografia

https://www.accessibilitamusei.beniculturali.it/luoghi-cultura/index

https://www.beniculturali.it/mibac/multimedia/MiBAC/documents/ | 3 | | 244354 | 28_plugin-LINEE_GUIDA_PER_IL_ SUPERAMENTO_DELLE_BARRIERE_ARCHITETTONICHE.pdf

https://www.cavazza.it/museoanteros

http://www.museoomero.it/

https://www.uiciechi.it/documentazione/paginetematiche/autonomia/elencazione\%20siti\%20museali20।9.doc

https://unric.org/it/wp-content/uploads/sites/3/2019/12/Convenzione_ONU-2.pdf

Autori

Vincenza Garofalo, Università degli Studi di Palermo, vincenza.garofalo@unipa.it

Elisa Azzurra Conigliaro, Università degli Studi di Palermo, azzuconigliaro@gmail.com

Alessia Tzimas, Università degli Studi di Palermo, alessiatzimas@gmail.com

Per citare questo capitolo: Garofalo Vincenza, Conigliaro Elisa Azzurra, Tzimas Alessia (2020). Rappresentazioni tattili/Tactile Representations. In Arena A., Arena M., Brandolino R.G., Colistra D., Ginex G., Mediati D., Nucifora S., Raffa P. (2020). Connettere. Un disegno per annodare e tessere. Atti del $42^{\circ}$ Convegno Internazionale dei Docenti delle Discipline della Rappresentazione/ Connecting. Drawing for weaving relationships. Proceedings of the 42th International Conference of Representation Disciplines Teachers. Milano: FrancoAngeli, pp. 2256-2275. 


\title{
Tactile Representations
}

\author{
Vincenza Garofalo \\ Elisa Azzurra Conigliaro \\ Alessia Tzimas
}

Abstract

Although very often people with disabilities have to be content with partially experiencing, for several years the attention of museum sites has increased towards the creation of projects and dedicated itineraries that allow tactile use of works and artifacts for the visually impaired.

The paper presents two case studies, which use 3D models for tactile installations.

In presence of visual impairment, it is important to strengthen the perceptive faculties by connecting the touch with the residual senses and providing different and parallel cognitive stimuli. The multisensory, tactile and auditory approach, created thanks to the mixture of 3D models and electronic components, favours the ability to abstraction and perception, allows to enjoy reproduction in a condition in which the original work cannot be enjoyed and makes the representative process understandable. Representation is communication of knowledge that is explored with multisensory experience.

Keywords

tactile representation, 3D modeling, 3D rinting, visually impaired, accessibility.
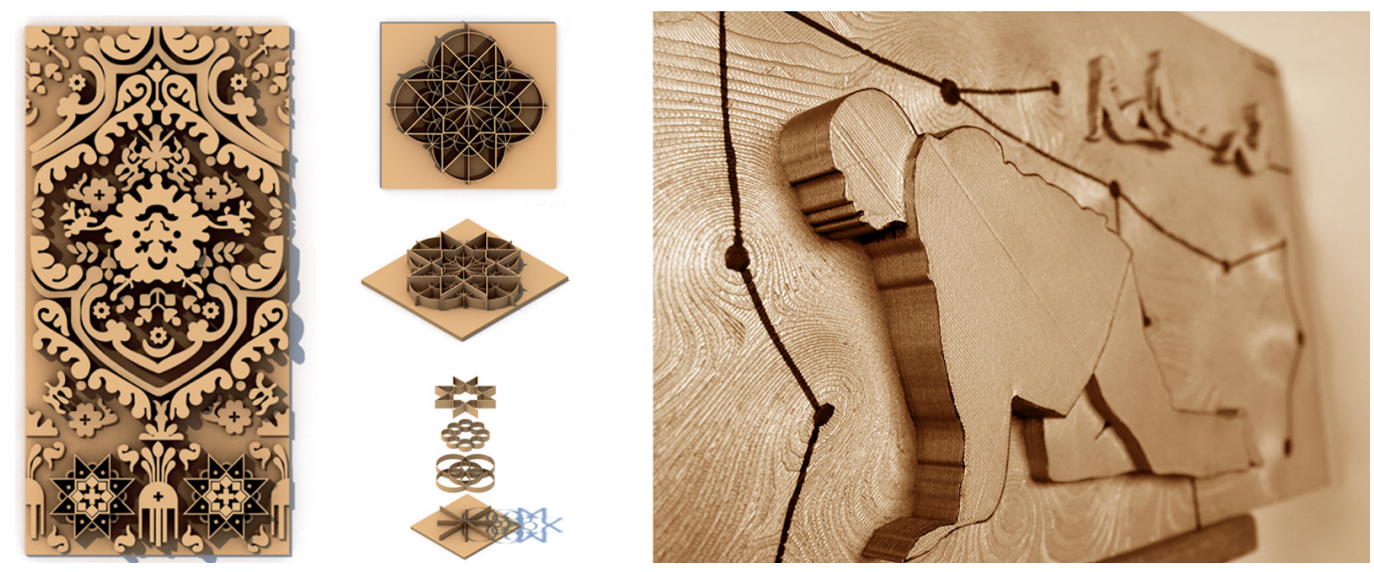


\section{Introduction}

Allowing access to works of art and places of cultural interest is essential to ensure full, easy and autonomous use for the disabled [I] To this end, in 2006 the UN Convention on the Rights of Persons with Disabilities [2] was approved and in 2008 in Italy the MIBACT (Ministry of Cultural Heritage and Activities and Tourism) drafted the Guidelines for overcoming architectural barriers in places of cultural interest [3].

Although very often people with disabilities have to be content with partially experiencing, for several years the attention of museum sites has increased towards the creation of projects and dedicated itineraries that allow tactile use of works and artifacts for the visually impaired. In Italy there are already many museums that have implemented good practices to allow accessibility to artistic works [4].

Among these, two institutions are mainly dedicated to the visually impaired. The Museo Tattile Statale Omero in Ancona is a structure dedicated to sensory exploration, created to allow blind people to learn about art and architecture through touch [5]. The Museo tattile di Pittura antica e moderna Anteros of the Istituto dei Ciechi Francesco Cavazza in Bologna houses a vast collection of three-dimensional reproductions of famous paintings [6].

The approach to the tactile reading of pictorial representations, translated into bas-relief, requires the disabled person to be able to perceive the external environment by using the extravisual residual senses, in order to strengthen his perceptive, cognitive and intellectual faculties (fig. I). This requires a preliminary preparation for reading which predisposes not only to the exploration of real objects, but also to their representation (figs. 2, 3).

"Approaching a blind person to iconic painting means not only bringing him closer to visual, figurative and/or mimetic, art which, if copies reality and transfigures it, but also introducing him to the principle of optical aberration and explaining to him that what the retinal vision perceives is an optical illusion that the mind decodes in order to perceive the real physiognomy of the observed object and the conventional notion that justifies its aberrated representation" [7].

Fig. I. Museo Anteros. Reproduction of the dead Christ by Andrea Mantegna. Perspective bas-relief. Mic pic / CC BY-SA: < https://creativecommons.org/licenses/ by-sa/4.0>.

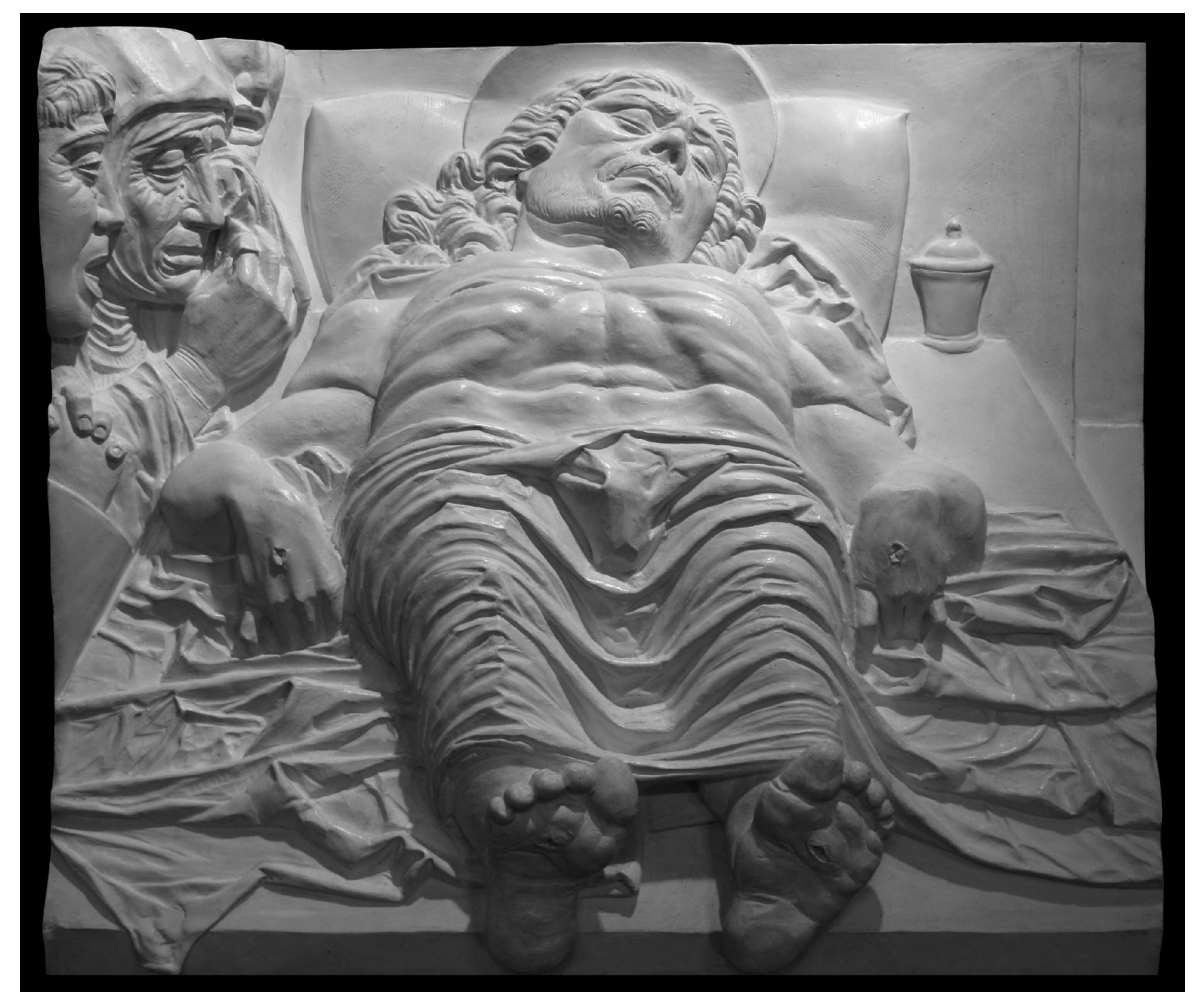




\section{Tactile exploration}

"A blind person, touching an object, outlines its contours like a sighted person for whom, looking at an object, a person, means detaching it from the background, focusing it, drawing it, delineating it with the mind" [8]. Among the forms of sensory exploration, tactile one allows the visually impaired to conceive an imaginative heritage adhering to reality and to achieve a mental representation of the work of art. This representation is constructed through an analytical and gradual process, which takes place over time and which requires abstraction and memory skills. However, excess information can be confusing. Therefore, it is important that the creation of 3D models for the blind is preceded by a careful analysis and discretisation of the main characteristics to be reproduced. The drawing to be reproduced in three dimensions must be simple, clear and concise. The touch, in fact, "is analytical and the perception of the whole is obtained through the organisation of the sequence of partial information. Synthesis is therefore a complex process and can become difficult if the representation exceeds certain dimensions (equal to the complete opening of two hands put together). In addition, tactile discrimination is limited and unable to understand very small details, so these must certainly be represented larger than those perceived by the sight [9]. The paper presents two case studies, which use 3D models for tactile installations [10].

Fig. 2. Museo Anteros. Tactile panel preparatory to learning perspective: $<$ www.cavazza.it $>$.

Fig. 3. Museo Anteros. Tactile panel preparatory to learning perspective: $<$ www.cavazza.it>.

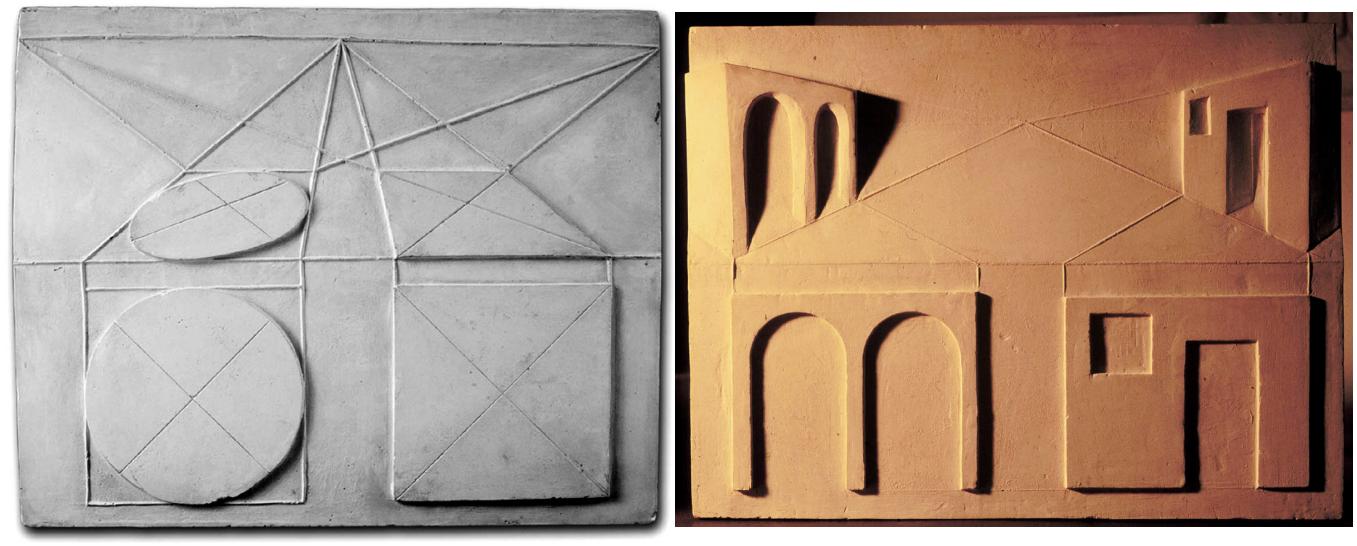

The first concerns the creation of 3D models for a photographic exhibition dedicated to migration, starting from photographs on the theme. Two shots were chosen. The first is by the Argentine photographer Juan Medina and depicts a migrant moving on all fours through the bathers on a Canarian beach, on which he has just landed. The second is a shot by Sebastiao Salgado taken in Ecuador in 1998 and represents a long line of Ecuadorian women on their way to the city to sell the products of their villages. The process of understanding through touch takes place with the recognition of the shapes, the composition of the image and the perspective space, to represent which both 3D models present the subjects on different levels, with respect to the laying plane. The digital model was created in successive steps: image analysis and selection of the elements to be reproduced, two-dimensional representation of the contour lines and their extrusion at different heights to simulate the depth planes of the composition (figs. 4, 5).

The second case study, designed for a permanent museum itinerary, concerns an installation that, through tactile exploration, allows the understanding of the articulated decoration of the fabric of a Moroccan wedding belt. In this case, since the model is made of a material other than the original, next to the tactile reproduction it is expected to place samples of fabric with embroidery, to simulate the feeling that is received from touching the authentic work. 


\section{Migration. A photographic project}

The project involves the creation of a 3D printing model designed for a photographic exhibition. The model is equipped with a sensorial touch that helps blind people to perceive the work through sounds. The first step concerned the analysis of the photo, in order to identify the main lines to be represented. To this end, the composition was discretised, to highlight the concepts to be transmitted and to make the reading of the work comprehensible to the visually impaired. As for the reproduction of the photo by Medina, Blender was used to represent the beach, which occupies the largest area of the shot. Starting from a mesh, various heights have been assigned to its vertices, in order to simulate the perspective depth of the beach surface. Rhinoceros was used, instead, to draw the contours that represent the man in the foreground of the scene, the three figures of bathers who are in the background and the sky. The outlines of the elements of the scene described above have been extruded, attributing them different heights, in order to simulate the perspective of the shot (fig. 6).
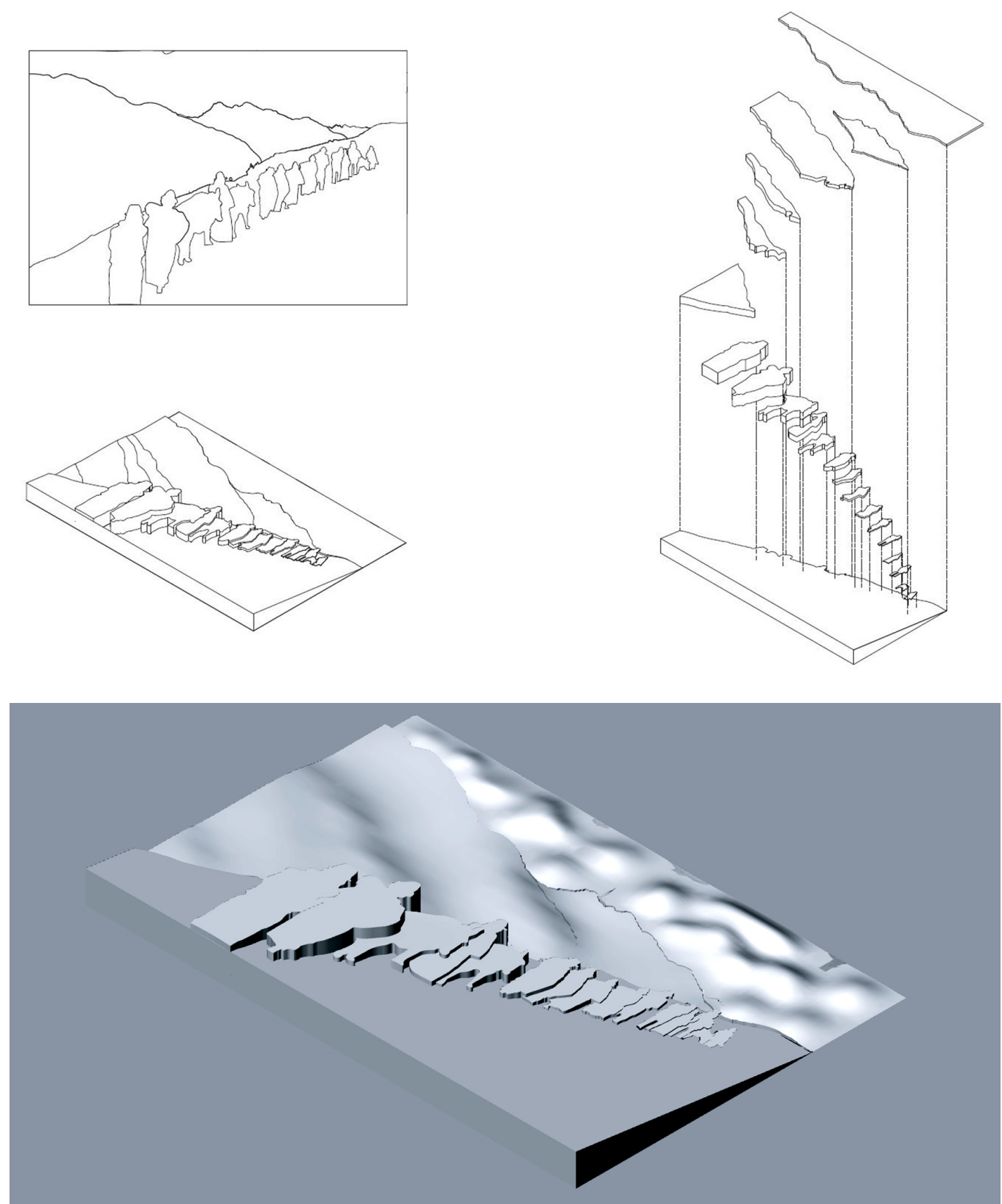
The digital model obtained by Blender and exported in STL format was imported into Rhinoceros, thus completing the three-dimensional reproduction of the whole photographic scene (fig. 7). The complete digital model, thus obtained, was finally exported in STL format and sent to the 3D printer to be converted into a physical model.

To make the experience even more immersive, we have chosen to connect to the physical model some sounds that can evoke the sound context of the represented environment. This was possible thanks to the application, in some selected points, of an electrically conductive paint, which draws a tactile circuit connected to an associated electronic board, capable of transmitting an input by the touch of the hands (fig. 8). The chosen sounds evoke the lapping of the waves, the voices of bathers, the steps on the sand and the lament of the castaway. These sounds are activated when the hand, in its exploratory path, meets the sensitive points of the model impregnated with paint and which correspond to the subject to which the sound is attributed. The visually impaired, who explores an object, first touches its edges and surfaces and then dwells on the details. Therefore, by touching the external

Fig. 6. Realisation of the 3D model that reproduces the shot by Juan Medina (graphic elaboration Elisa Azzurra Conigliaro).
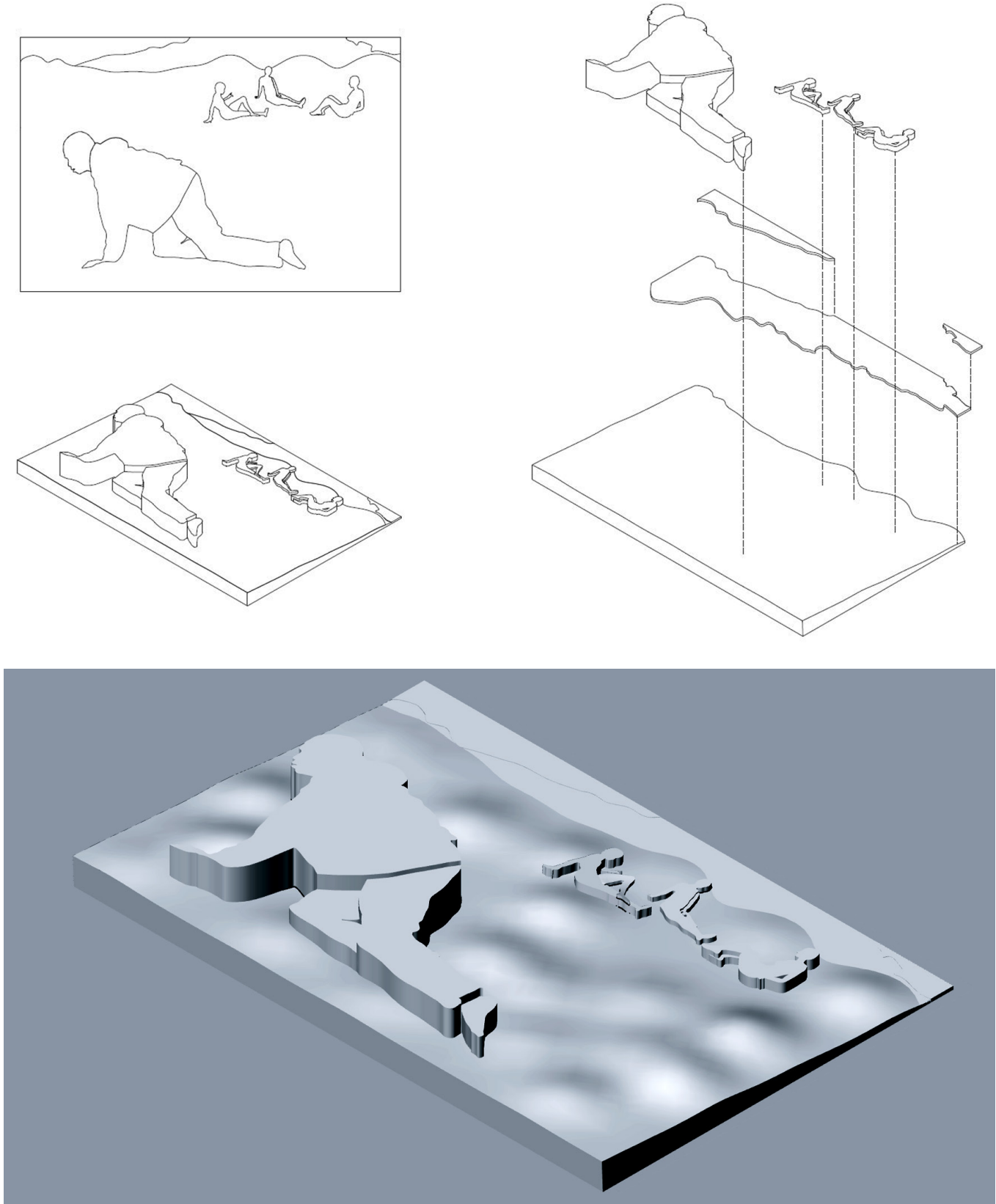
profile of the physical model, you can only hear the sound of the sea and, gradually, touching all the other elements of the composition, you can also hear the other sounds. In this way, the blind person completes the total experience of the shot.

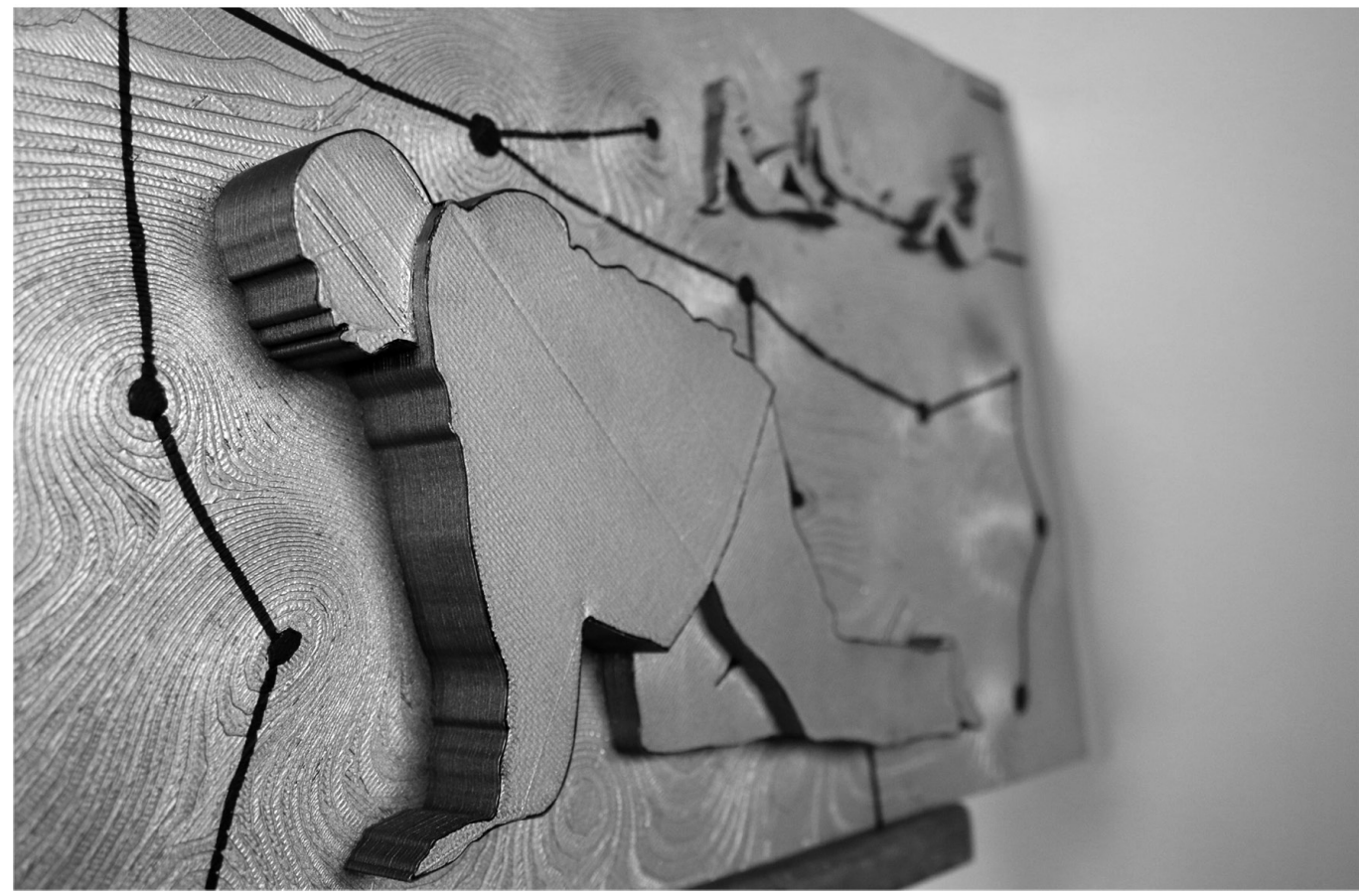

\section{Tactile plots}

The Museo delle Trame Mediterranee in Gibellina houses works of art that tell the cultural history of the Mediterranean through the comparison of the artifacts, the comparison of shapes, techniques and decorations. The tactile installation, which is presented here, was designed as part of a multisensory museum itinerary, designed for the Museum, which consists of the integration between the tactile description of the works and the path guided by the senses. The itinerary winds along three rooms: the first concerns the touch and the exploration of the fabrics, the second concerns the sense of smell and the description of the ceramics, the third is dedicated to hearing and detailed exploration of the panels that analyse the decorations of the objects of the exhibited collection.

To guide blind and partially sighted visitors along the museum itinerary, it is planned to provide them with a card having two chips. The first allows a connected computer to detect the presence of visitors; for this purpose, 3D mapping of the rooms must be carried out in advance. Visitors can freely and independently move obtaining, through the chip, instant information of what is happening in the spaces. The second chip uses RFID (Radio Frequency Identification) automatic identification technology which is based on the propagation of electro-magnetic waves in the air, allowing the automatic and remote detection of static and moving objects and people. A text-to-speech software allows the disabled person to receive, via a bluetooth headset, the voice information on the path to follow, any obstacles or points of interest in the room.

To simulate one of the tactile installations of the room dedicated to the exploration of fabrics, we decided to represent an element of the museum's collection. It is a long belt, dating back to the early 19th century, which is part of the men's wedding dress used in 
Fig. 9. Moroccan belt: in the center the texture, on the right the colour analysis (graphic elaboration Alessia Tzimas).
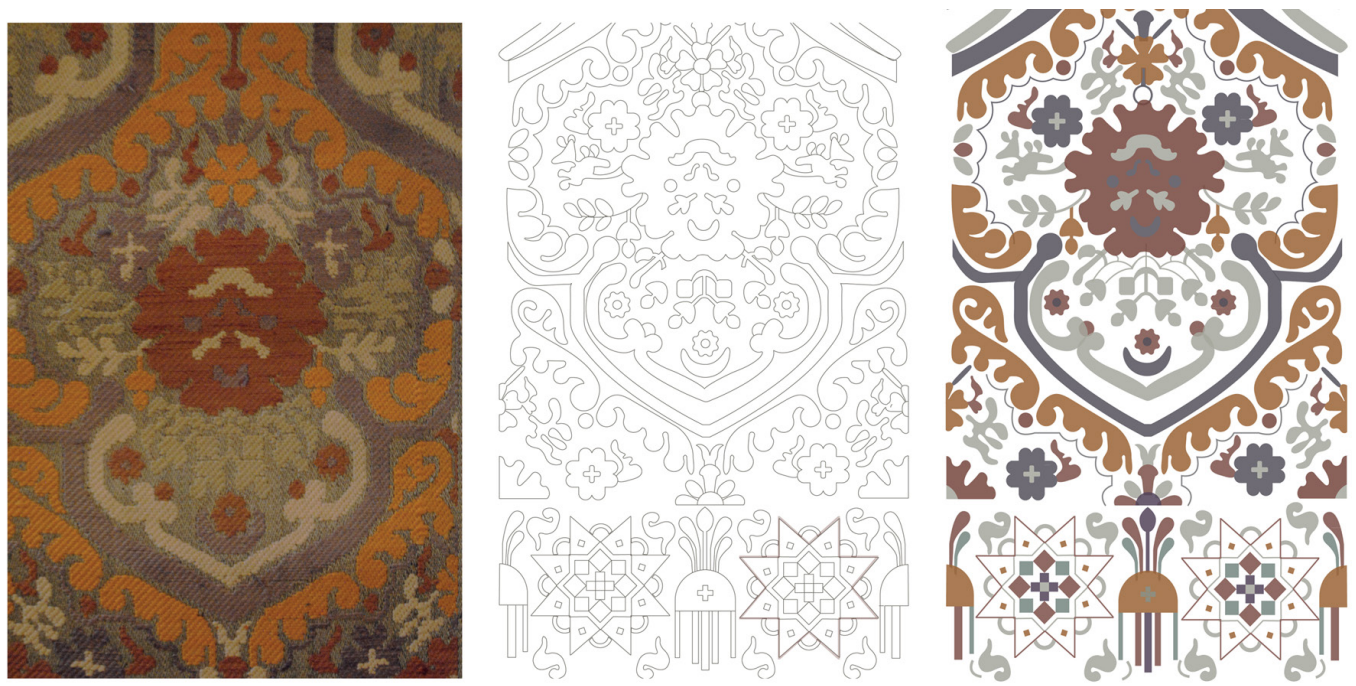

many communities in southern Morocco (fig. 9). Made with precious fabrics and motifs that show articulated alternating weaves along the entire length, it is a testimony of the Islamic decorative language. The marked geometry of the forms and their constant repetitiveness are closely linked to religious reasons, since Muslim spirituality sees in the contemplation of forms repeated indefinitely the possibility of reaching the divine.

The final part of the belt shows the motif of the two rotated eight-pointed stars, typical of the Islamic tradition and found in various objects of the Museum collection, coming from different places and made in different periods.

In order to create a tactile representation that would make the textures of the blind comprehensible, the geometries and composition of the decoration were first analysed (figs. I0, II). These geometries were extruded to create a 3D model, attributing a different height to the different colours areas of the belt (fig. 12). This procedure was aimed at giving the user a correspondence between colours and geometries as close as possible to the composition of the artefact.The modeling process was preliminary to the 3D printing of a panel that reproduces the belt and which can be used by the visually impaired using touch. It is also possible to use textures recognisable to the touch to be applied to the surfaces of the model to further differentiate the colours.
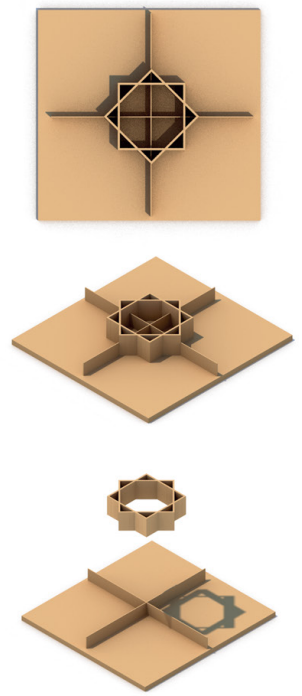
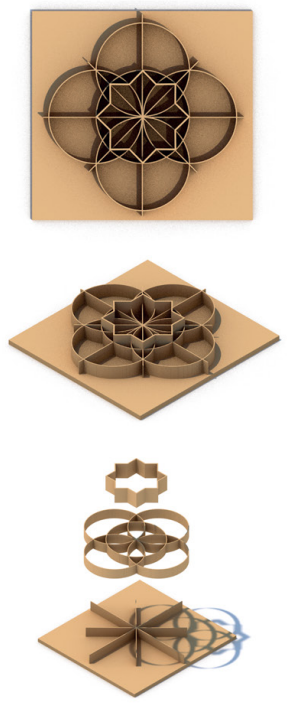
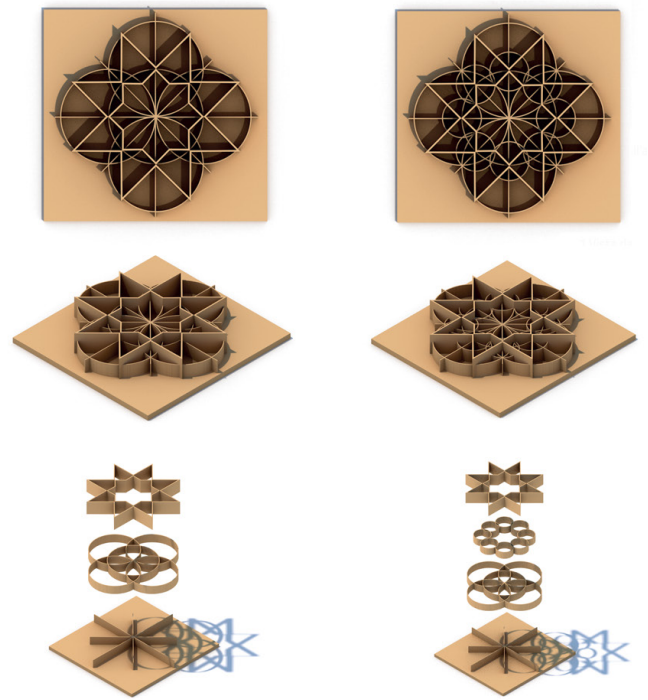


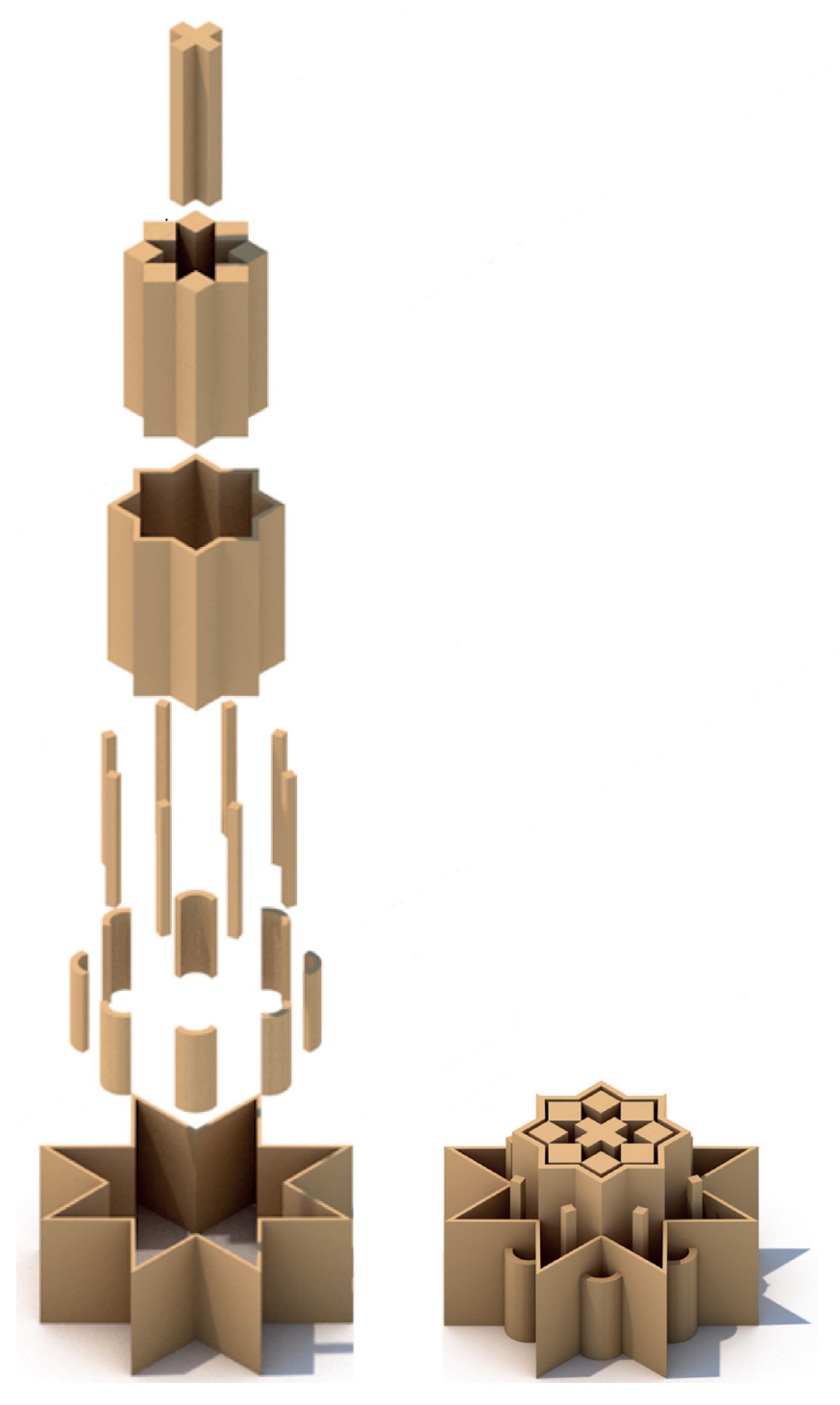

Fig. 12. Digital 3D

model of the end part

of the belt: the different

extrusion heights indicate

different colours (graphic

elaboration Alessia
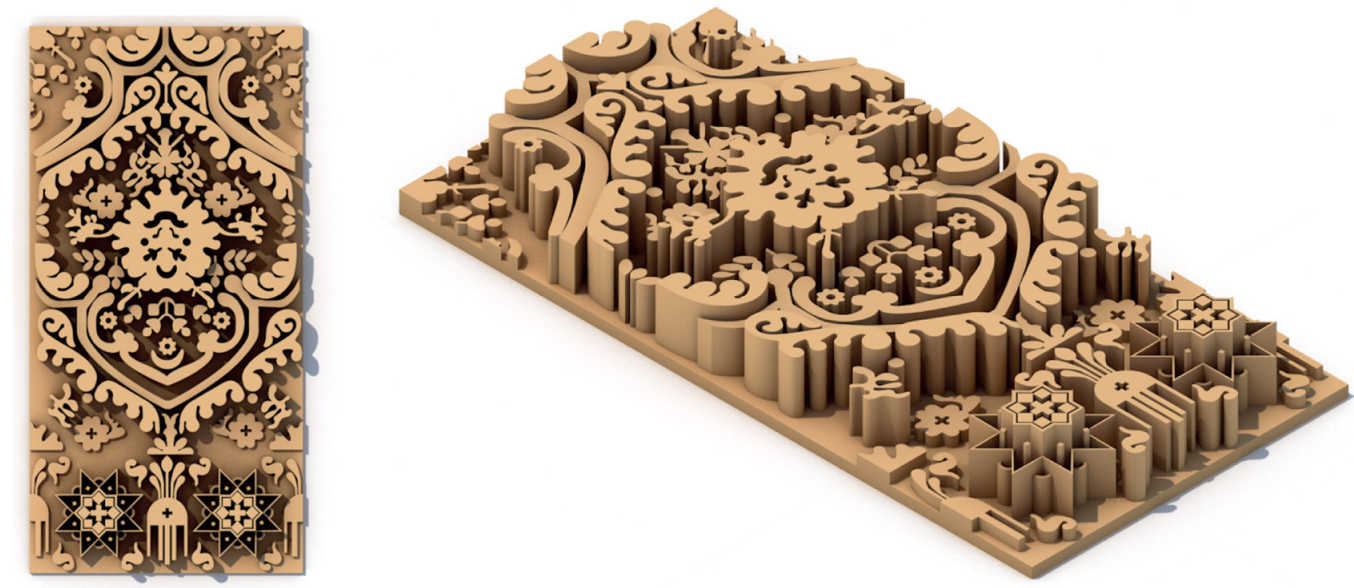


\section{Conclusions}

The two installation projects for the visually impaired presented here have a double educational and inclusive value. The didactic character lies in the possibility for blind people to get to know the analysed works through their three-dimensional representation, which is constructed following a careful process of analysis of the forms and transmission of meaning. The inclusive aspect is what makes the works accessible, understandable and usable, allowing visually impaired people to eliminate barriers.

In presence of visual impairment, it is important to strengthen the perceptive faculties by connecting the touch with the residual senses and providing different and parallel cognitive stimuli. The multisensory, tactile and auditory approach, created thanks to the mixture of 3D models and electronic components, favours the ability to abstraction and perception, allows to enjoy reproduction in a condition in which the original work cannot be enjoyed and makes the representative process understandable.

Representation is communication of knowledge that is explored with multisensory experience.

\section{Notes}

[I] The paragraph "Tactile exploration" together with the Introduction and Conclusions are written by Vincenza Garofalo. The paragraph "Migration. A photographic project" is written by Elisa Azzurra Conigliaro and the paragraph "Tactile plots" is written by Alessia Tzimas.

[2] See: <https://unric.org/it/wp-content/uploads/sites/3/2019/12/Convenzione_ONU-2.pdf>.

[3] See: <https://www.beniculturali.it/mibac/multimedia/MiBAC/documents/I 3 I I 244354 I 28_plugin-LINEE_GUIDA_PER_IL_ SUPERAMENTO_DELLE_BARRIERE_ARCHITETTONICHE.pdf>.

[4]The updated list of museum institutions that present usable exhibitions and dedicated itineraries can be consulted at https:// www.uiciechi.it/documentazione/paginetematiche/autonomia/elencazione\%20siti\%20museali20|9.doc $>$. To access: <however information on the accessibility of museums and archaeological areas, consult https://www.accessibilitamusei.beniculturali.it/ luoghi-cultura/index>

[5] See: <http://www.museoomero.it/>

[6] See: <https://www.cavazza.it/museoanteros>.

[7] Secchi Loretta, Gualandi Paolo (2006). Logiche di ideazione e realizzazione della pittura tridimensionale per una didattica speciale delle arti. In Museo Tattile Statale Omero (a cura di). L'arte a portata di mano. Roma: Armando Editore.

[8] Guerra Lisi Stefania, Stefani Gino (2006). Sinestesia e MusicArTerapia nella Globalità dei Linguaggi. In Museo Tattile Statale Omero (a cura di). L'arte a portata di mano. Roma: Armando Editore, pp. 70-7I.

[9] https://www.beniculturali.it/mibac/multimedia/MiBAC/documents// 3 | I 244354 I 28_plugin-LINEE_GUIDA_PER_IL_ SUPERAMENTO_DELLE_BARRIERE_ARCHITETTONICHE.pdf, pp. 23-24.

[I0] 3D printing allows to obtain physical models which, although they are reliable for their geometric and dimensional characteristics, nevertheless present surfaces that are not smooth to the touch. The roughness of the material is not suitable for tactile exploration; therefore, it is advisable to foresee the smoothing of the printed model to improve the quality of its surface.

References

Arnheim Rudolf (1994). Per la salvezza dell'arte. Milano: Feltrinelli.

Bellini Andrea (a cura di) (2000). Toccare l'arte. L'educazione estetica di ipovedenti e non vedenti. Roma: Armando Editore.

Conigliaro Elisa Azzurra (2018). Migrazioni. Un progetto fotografıco tattile. Tesi di laurea, Università di Palermo. Relatore prof. Vincenza Garofalo,

Gombrich Ernst H., Hochberg Julian, Black Max (1978). Arte, percezione e realtà. Torino: Einaudi.

Lederman Susan J., Klatzky Roberta L. (1987). Hand Movements: A window into Haptic Object Recognition. In Cognitive Psychology, 19, pp. 342-68.

Merleau-Ponty Maurice (2003). Fenomenologia della percezione. (Traduzione di Andrea Bonomi). Milano: Bompiani. (Ed. orig. (1945) Phénoménologie de la perception. Paris: Gallimard).

Mottola Molfino Alessandra (2004). L'etica dei musei. Torino: Umberto Allemandi.

Museo Tattile Statale Omero (a cura di). (2006). L'arte a portata di mano. Roma: Armando Editore.

Pallasmaa Juhani (2007). Gli occhi della pelle. L'architettura e i sensi. Prefazione di Steven Holl. Milano: Jaca Book. (Ed. orig. (2005) The Eyes of the Skin. Architecture and the Senses). New York: John Wiley. 
Secchi Loretta (2007). Andrea Mantenga e la didattica speciale: nuove acquisizioni del Museo Anteros di Bologna. In Bollettino Anisa (Associazione Nazionale Insegnanti Storia dell'Arte) 27, Gennaio-Agosto, pp. 40-57.

Tzimas Alessia (20 I6). Trame tattili. Un percorso multimediale per il museo di Gibellina. Tesi di laurea, Università di Palermo. Relatore prof. Vincenza Garofalo.

\section{website}

https://www.accessibilitamusei.beniculturali.it/luoghi-cultura/index

https://www.beniculturali.it/mibac/multimedia/MiBAC/documents/| 3 | | 244354|28_plugin-LINEE_GUIDA_PER_IL_ SUPERAMENTO_DELLE_BARRIERE_ARCHITETTONICHE.pdf

https://www.cavazza.it/museoanteros

http://www.museoomero.it/

https://www.uiciechi.it/documentazione/paginetematiche/autonomia/elencazione\%20siti\%20museali20l9.doc (consultato a gennaio 2020)

https://unric.org/it/wp-content/uploads/sites/3/2019/12/Convenzione_ONU-2.pdf

\section{Authors}

Vincenza Garofalo, Università degli Studi di Palermo, vincenza.garofalo@unipa.it

Elisa Azzurra Conigliaro, Università degli Studi di Palermo, azzuconigliaro@gmail.com

Alessia Tzimas, Università degli Studi di Palermo, alessiatzimas@gmail.com

To cite this chapter. Garofalo Vincenza, Conigliaro Elisa Azzurra, Tzimas Alessia (2020). Rappresentazioni tattili/Tactile Representations. In Arena A., Arena M., Brandolino R.G., Colistra D., Ginex G., Mediati D., Nucifora S., Raffa P. (2020). Connettere. Un disegno per annodare e tessere. Atti de $42^{\circ}$ Convegno Internazionale dei Docenti delle Discipline della Rappresentazione/ Connecting. Drawing for weaving relationships. Proceedings of the 42th International Conference of Representation Disciplines Teachers. Milano: FrancoAngeli, pp. 2256-2275. 